\title{
Current Status of Therapeutic Drug Monitoring of 5-Fluorouracil Prodrugs
}

\author{
YASUHIRO HASHIMOTO*, YOICHIRO YOSHIDA*, TEPPEI YAMADA, NAOYA AISU, \\ GUMPEI YOSHIMATSU, FUMIHIRO YOSHIMURA and SUGURU HASEGAWA
}

Department of Gastroenterological Surgery, Faculty of Medicine, Fukuoka University, Fukuoka, Japan

\begin{abstract}
In recent years, therapeutic drug monitoring (TDM) of intravenous administration of 5-fluorouracil (5-FU) has resulted in reduced toxicity and improved efficacy. Prodrugs of 5-FU were developed to reduce toxicity, extend the duration of action, and increase tumour selectivity of 5-FU. These drugs are important in daily practice because of their ease of administration. Dose adjustment of 5-FU prodrugs by TDM is expected to reduce its toxicity and improve its efficacy. This review focuses on data from a recent study of personalized treatment using TDM of 5-FU and its prodrugs.
\end{abstract}

Therapeutic drug monitoring (TDM) refers to measuring the concentration of a drug in a biological sample to individualize the drug dose, in order to improve drug efficacy and reduce toxicity (1). This method has been mainly developed and put into practical use for antibacterial drugs and antiepileptic drugs and has shown beneficial results. In recent years, TDM has been considered an important strategy to optimize the therapeutic effects of anticancer drugs with a very narrow therapeutic index and high cytotoxicity (2).

In current gastrointestinal cancer care, 5-fluorouracil (5FU) is a key drug in cancer treatment, and is the backbone of chemotherapy, especially for colorectal cancer treatment. The dosing schedule originally involved administering a

This article is freely accessible online.

*These Authors contributed equally to this study.

Correspondence to: Dr. Yasuhiro Hashimoto, Department of Gastroenterological Surgery, Faculty of Medicine, Fukuoka University, 7-45-1, Nanakuma, Jonan-ku, Fukuoka, 814-0180, Japan. Tel: +81 928011011 ext. 3425, Fax: +81 928013600, e-mail: y.sp0424@gmai.com

Key Words: 5-FU prodrugs, therapeutic drug monitoring, personalized treatment, capecitabine, review. bolus and evolved into a continuous intravenous schedule, followed by an intermittent intravenous schedule, and then a bolus and intermittent intravenous hybrid schedule. In addition, treatment results were dramatically improved using a combination regimen with oxaliplatin or irinotecan or a combination including molecular-targeted drugs such as bevacizumab, cetuximab, and panitumumab. In a recent report, 5-FU was also used for neoadjuvant and adjuvant chemotherapy and showed good therapeutic results $(3,4)$.

In daily practice, the dosage of $5-\mathrm{FU}$ is generally calculated based on the patient's body surface area (BSA). However, BSA has been shown to be an insufficient predictor of systemic drug exposure (5-7). In addition, recent studies have reported a relationship between drug exposure, toxicity and efficacy (8). In previous reports, the response rate was significantly improved and adverse events were reduced for patients who underwent TDM-based 5-FU dose adjustment compared with patients treated with conventional 5-FU administration (9-12). Appropriate adjustment of the 5-FU blood concentration can improve both the safety and efficacy of treatment. This review focuses on recent studies of personalized treatment using TDM of 5-FU and its prodrug.

\section{5-FU Prodrugs}

A prodrug is defined as a compound that undergoes biotransformation before exhibiting its therapeutic effect (13). By converting a drug into a prodrug, the chemical stability, solubility, oral bioavailability, blood-brain barrier permeability, tissue-selective activation, toxicity reduction, optimization of action speed or duration, and acceptability can be improved (14, 15). Prodrugs of 5-FU were developed to reduce toxicity, extend the duration of action, and increase tumour selectivity.

Tegafur. Tegafur was developed by Hiller et al. (16). It is rapidly absorbed from the gastrointestinal tract by oral administration. The absorbed tegafur is metabolized by cytochrome P450, mainly in the liver. Therefore, it is 
gradually converted into 5-FU, and a high concentration of 5-FU persists in the blood and tissue for a long time. Tegafur is also converted to 5-FU by pyrimidine-nucleosidephosphorylase, which is present in the liver, small intestine, and tumour tissues.

UFT. Tegafur is gradually converted to 5-FU after oral administration but is simultaneously catabolized and degraded by dihydropyrimidine dehydrogenase (DPD). To exert a substantial anti-tumour effect, it is necessary to maintain high levels of 5-FU in the blood and tissues. UFT is a drug that contains uracil, which inhibits the degradation of 5-FU by DPD. It is the first anticancer drug formulated by biochemical modulation (17). The uracil (molar ratio of tegafur: uracil=1:4) contained in UFT competitively inhibits the degradation of 5FU by DPD but does not inhibit phosphorylation; therefore, the antitumour effect is enhanced. Furthermore, 5-FU and its phosphorylated metabolite are maintained at high concentrations in tumours $(18,19)$.

$S-1$. S-1 was developed to enhance the effect of UFT and reduce side effects. It is composed of tegafur, gimeracil, and oteracil in a molar ratio of 1:0.4:1. Gimeracil inhibits the DPD enzyme more potently (200-fold) than uracil (20). Oteracil is distributed at a high concentration in the gastrointestinal tract and inhibits the phosphorylation of 5FU, thereby enhancing the antitumour effect and reducing gastrointestinal toxicity (21).

Carmofur. Carmofur was synthesized and developed by Hoshi et al. in Japan in 1975 (22). Carmofur releases 5-FU without the intervention of drug metabolizing enzymes such as DPD by attaching a hexyl group to the carbamoyl bond of 5-FU. It is rapidly absorbed from the gastrointestinal tract and gradually releases 5-FU into the blood, lymph, ascites, and tissues. Carmofur is also a very powerful acid ceramidase inhibitor. Ceramide affects the survival, growth, and death of cancer cells (23).

Doxifluridine. Doxifluridine (5'-DFUR) was synthesized by Cook et al. in 1976. 5'-DFUR itself has no cytostatic effect and is converted to 5-FU by thymidine phosphorylase (TP), which is abundant in tumour tissues. In addition, TP activity is considered to be higher in tumour tissues than in surrounding normal tissues, and it is thought that 5-FU is selectively increased in tumour tissues. TP is a unique enzyme and was found to be the same protein as platelet-derived endothelial cell growth factor, which has an angiogenic action $(24,25)$. Its expression level has been reported to correlate with vessel density and prognosis $(26,27)$.

Capecitabine. Capecitabine is converted to 5-FU via a threestep activation. First, capecitabine is metabolized in the liver by carboxylesterase, which has low activity in the intestinal epithelium. Next, it is sequentially metabolized by cytidine deaminase, which is highly expressed in the liver and tumour tissue. Finally, it is converted to 5-FU by TP, which exhibits high activity in tumour tissue. This multi-step metabolism reduces gastrointestinal and bone marrow toxicity and results in high tumour selectivity (28).

\section{Current Status of TDM Measurement Methods}

Various blood concentration measurement methods have been developed for the analysis of 5-FU. One commonly method that has been reported for measurement of the blood concentration after 5-FU administration is liquid chromatography-tandem mass spectrometry (LC-MS). This method can also be used to measure metabolites of capecitabine, which is a prodrug of 5-FU (10-12).

However, LC-MS is currently only available in specialized clinical laboratories, and has poor versatility. Recently, an My5-FU immunoassay was developed to rapidly measure 5FU levels in human plasma (29). The assay is based on the aggregation of nanoparticles, which is inversely proportional to the amount of 5-FU in the sample. The My5-FU assay showed comparable performance to various analysis methods such as LC-MS and other commonly used clinical analysis methods. The My-5FU assay can measure the blood concentration of 5-FU using a general clinical test instrument (30). As a result, TDM has become easier in daily medical care. However, at present, there are only a few reports describing the measurement of the blood concentration of 5FU prodrugs using this method. It is also necessary to verify that accurate TDM of 5-FU prodrugs can be achieved.

\section{Individualized Treatment with TDM of 5-FU and 5-FU Prodrugs}

TDM of 5-FU allows dose adjustment of 5-FU according to the plasma concentration. Some reports have described the clinical effects of this process such as reduced toxicity and improved efficacy (Table I) (9, 31-41). Two 5-FU dose adjustment algorithms have been mainly used in recent reports. The first target for 5-FU is an area under the curve (AUC) of $20-25 \mathrm{mg} \cdot \mathrm{h} / \mathrm{l}$, and the second is an AUC of $20-$ $30 \mathrm{mg} \cdot \mathrm{h} / \mathrm{l}$. The former algorithm was reported by Gamelin. This is the only prospective randomized TDM study that has been conducted, and demonstrated reduced toxicity and a trend toward improved survival (10). The latter is the dosing algorithm reported by Kaldate (42). Wilhelm quickly reached the target 5-FU AUC, demonstrating that pharmacokinetic variability could be reduced.

However, various research reports have described the measurement of the blood concentration of 5-FU prodrugs using TDM for the purpose of pharmacokinetic verification. 
Table I. Summary of personalized treatment report with TDM of 5-FU.

\begin{tabular}{|c|c|c|c|c|c|c|c|c|c|c|}
\hline $\begin{array}{l}\text { Authors } \\
\text { (Ref) }\end{array}$ & Year & Patients & Cancer & Regimen & $\begin{array}{l}\text { First } \\
5-\mathrm{FU} \\
\text { dosage }\end{array}$ & $\begin{array}{l}\text { TDM } \\
\text { analysis }\end{array}$ & $\begin{array}{l}\text { Sampling } \\
\text { time }\end{array}$ & $\begin{array}{l}\text { Sampling } \\
\text { day } \\
\text { (Day) }\end{array}$ & $\begin{array}{c}\text { Dose } \\
\text { adjustment }\end{array}$ & Effectiveness \\
\hline $\begin{array}{l}\text { Santini } \\
(31)\end{array}$ & 1989 & 170 & $\begin{array}{l}\text { Head\& } \\
\text { Neck }\end{array}$ & $\begin{array}{l}5-\mathrm{FU} \\
\text { cisplatin }\end{array}$ & $1,000 \mathrm{mg} / \mathrm{m}^{2}$ & HPCL & 8a.m, 5p.m & $1,2,3,4,5$ & $\begin{array}{l}\text { 5-FU AUC 0-3 days } \\
\text { was analyzed in } \\
\text { real-time to decide } \\
\text { the dose of 5-FU. } \\
5 \text {-FU reduction } \\
\text { between } 30 \text { and } 50 \% \text {. }\end{array}$ & $\begin{array}{l}\text { Reduced toxicity. } \\
\text { Improvement in ORR. }\end{array}$ \\
\hline $\begin{array}{l}\text { Gamelin } \\
(32)\end{array}$ & 1998 & 152 & $\mathrm{CRC}$ & 5-FU,LV & $1,300 \mathrm{mg} / \mathrm{m}^{2}$ & NA & NA & NA & $\begin{array}{c}\text { The initial dose of 5-FU } \\
\text { was adapted weekly } \\
\text { according to 5-FU } \\
\text { plasma levels. }\end{array}$ & $\begin{array}{l}\text { Reduced toxicity. } \\
\text { Improvement } \\
\text { in ORR, OS. }\end{array}$ \\
\hline $\begin{array}{l}\text { Fety } \\
(33)\end{array}$ & 1998 & 106 & $\begin{array}{l}\text { Head\& } \\
\text { Neck }\end{array}$ & $\begin{array}{l}5-\mathrm{FU} \\
\text { cisplatin }\end{array}$ & $1,000 \mathrm{mg} / \mathrm{m}^{2}$ & HPLC & 8a.m, 5p.m & $1,2,3,4$ & $\begin{array}{l}\text { 5-FU dose adjustment } \\
\text { according to 5-FU } \\
\text { AUC0-48 hours. }\end{array}$ & $\begin{array}{l}\text { Reduced toxicity. } \\
\text { Response rates } \\
\text { were equivalent. }\end{array}$ \\
\hline $\begin{array}{l}\text { Ychou } \\
\text { (34) }\end{array}$ & 2003 & 53 & $\begin{array}{l}\text { Head\& } \\
\text { Neck }\end{array}$ & LV5FU2 & $\begin{array}{c}400 \mathrm{mg} / \mathrm{m}^{2} / \\
\text { day bolus } \\
600 \mathrm{mg} / \mathrm{m}^{2} / \text { day }\end{array}$ & HPLC & $\begin{array}{c}0 \mathrm{~h}, 2 \mathrm{~h} \\
20 \mathrm{~min}, 20 \mathrm{~h}\end{array}$ & 1,2 & $\begin{array}{l}\text { Cycle } 2 \text { dose } \\
\text { adjustment depending } \\
\text { on cycle } 1 \text { toxicity. }\end{array}$ & $\begin{array}{l}\text { Reduced toxicity. } \\
\text { No pharmacokinetic } \\
\text { variables were } \\
\text { significant for OS. }\end{array}$ \\
\hline $\begin{array}{l}\text { Gamelin } \\
\text { (9) }\end{array}$ & 2008 & 208 & $\mathrm{mCRC}$ & 5-FU,LV & $1,500 \mathrm{mg} / \mathrm{m}^{2}$ & NA & $3 \mathrm{~h}, 7 \mathrm{~h}$ & 1 & $\begin{array}{l}\text { 5-FU AUC } \\
20-25 \mathrm{mg} \cdot \mathrm{h} / 1\end{array}$ & $\begin{array}{l}\text { Fewer grade } \\
\text { 3/4 toxicities. } \\
\text { Trend to higher } \\
\text { survival rate. }\end{array}$ \\
\hline $\begin{array}{l}\text { Saam } \\
(35)\end{array}$ & 2011 & 356 & $\mathrm{CRC}$ & $\begin{array}{l}\text { FOLFOX6 } \\
\text { FOLFIRI }\end{array}$ & NA & $\begin{array}{c}\text { Immuno- } \\
\text { assay } \\
\left(\text { Ondose }^{\circledR}\right)\end{array}$ & $\begin{array}{l}2 \mathrm{~h} \text {, } \\
\text { end of } \\
\text { infusion }\end{array}$ & 1,2 & $\begin{array}{c}\text { 5-FU AUC } \\
20-24 \mathrm{mg} \cdot \mathrm{h} / 1\end{array}$ & NA \\
\hline $\begin{array}{l}\text { Capitain } \\
(36)\end{array}$ & 2012 & 157 & $\mathrm{mCRC}$ & FOLFOX6 & $\begin{array}{l}400 \mathrm{mg} / \mathrm{m}^{2} / \\
\text { day bolus } \\
2500 \mathrm{mg} / \mathrm{m}^{2}\end{array}$ & NA & NA & NA & $\begin{array}{c}5-\mathrm{FU} \text { AUC } \\
20-25 \mathrm{mg} \cdot \mathrm{h} / 1\end{array}$ & $\begin{array}{l}\text { Reduced toxicity. } \\
\text { Improvement in } \\
\text { ORR, OS, PFS. }\end{array}$ \\
\hline $\begin{array}{l}\text { Kline } \\
(37)\end{array}$ & 2014 & 84 & $\mathrm{mCRC}$ & mFOLFOX6 & NA & $\begin{array}{l}\text { Immuno- } \\
\text { assay } \\
\left(\text { Ondose }^{\circledR}\right)\end{array}$ & NA & NA & $\begin{array}{c}\text { 5-FU AUC } \\
20-24 \mathrm{mg} \cdot \mathrm{h} / 1\end{array}$ & $\begin{array}{l}\text { Reduced toxicity. } \\
\text { Improvement in PFS. }\end{array}$ \\
\hline $\begin{array}{l}\text { Patel } \\
(38)\end{array}$ & 2014 & 70 & $\mathrm{mCRC}$ & mFOLFOX6 & $\begin{array}{c}400 \mathrm{mg} / \mathrm{m}^{2} / \\
\text { day bolus } \\
2,500 \mathrm{mg} / \mathrm{m}^{2}\end{array}$ & $\begin{array}{l}\text { Immuno- } \\
\text { assay }\end{array}$ & $2 \mathrm{~h}, 44 \mathrm{~h}$ & 1,2 & $\begin{array}{c}\text { 5-FU AUC } \\
20-25 \mathrm{mg} \cdot \mathrm{h} / 1\end{array}$ & Reduced toxicities. \\
\hline $\begin{array}{l}\text { Wilhelm } \\
\text { (39) }\end{array}$ & 2016 & 75 & $\mathrm{mCRC}$ & $\begin{array}{l}\text { AIO } \\
\text { FOLFOX6 } \\
\text { FUFOX }\end{array}$ & NA & $\begin{array}{l}\text { Immuno- } \\
\text { assay } \\
\left(\mathrm{My} 5 \mathrm{FU}^{\circledR}\right)\end{array}$ & $\begin{array}{l}18 \mathrm{~h} \\
4 \mathrm{~h} \text { before } \\
\text { the end of } \\
\text { infusion }\end{array}$ & 1,2 & $\begin{array}{c}\text { 5-FU AUC } \\
20-30 \mathrm{mg} \cdot \mathrm{h} / 1\end{array}$ & Reduced toxicities. \\
\hline $\begin{array}{l}\text { Denda } \\
(40)\end{array}$ & 2016 & 48 & $\mathrm{mCRC}$ & mFOLFOX7 & $2,400 \mathrm{mg} / \mathrm{m}^{2}$ & $\begin{array}{l}\text { Immuno- } \\
\text { assay } \\
\left({\left.\mathrm{My} 5 \mathrm{FU}^{\circledR}\right)}\right.\end{array}$ & $18 \mathrm{~h}, 36 \mathrm{~h}$ & 1,2 & $\begin{array}{l}\text { 5-FU AUC } \\
20-30 \mathrm{mg} \cdot \mathrm{h} / 1\end{array}$ & $\begin{array}{l}\text { Reduced toxicity. } \\
\text { Improvement in } \\
\text { ORR, OS, PFS. }\end{array}$ \\
\hline $\begin{array}{l}\text { Deng } \\
(41)\end{array}$ & 2019 & 153 & $\mathrm{mCRC}$ & $\begin{array}{l}\text { FOLFOX } \\
\text { FOLFIRI }\end{array}$ & NA & $\begin{array}{l}\text { Immuno- } \\
\text { assay } \\
\left(\text { My5FU }^{\circledR}\right)\end{array}$ & NA & NA & $\begin{array}{l}\text { 5-FU AUC } \\
20-30 \mathrm{mg} \cdot \mathrm{h} / 1\end{array}$ & $\begin{array}{l}\text { 5-FU dose well } \\
\text { without an increased } \\
\text { 5-FU toxicity. }\end{array}$ \\
\hline
\end{tabular}

mCRC: Metastatic colorectal cancer; LV: leucovorin; HPLC: high performance liquid chromatography; TDM: therapeautic drug monitoring; AUC: area under the curve; ORR: overall response rate; OS: overall survival; PFS: progression-free survival.

Kochi et al. performed TDM of S-1 before and after gastrectomy and reported that the pharmacokinetics of 5-FU did not change regardless of whether partial or total gastrectomy was performed (43). Lacrimal tract disorders caused by S-1 are well-known adverse events. Yasui measured drug concentrations in the plasma and tears, and demonstrated that 5-FU and gimeracil concentrations exhibit a positive correlation (44). This report is expected to contribute to the establishment of preventive measures for lacrimal disorders.

Among 5-FU prodrugs, various studies have been conducted to elucidate the pharmacokinetics of capecitabine, which is used to treat many types of carcinoma. Gieschke reported that 5-FU, 5'-DFUR, and fluoro- $\beta$-alanine (FBAL) 
Table II. Summary of personalized treatment report with TDM of 5-FU prodrugs

\begin{tabular}{|c|c|c|c|c|c|c|c|c|c|c|c|}
\hline $\begin{array}{l}\text { Authors } \\
\text { (Ref) }\end{array}$ & Year & Patients & Cancer & Status & $\begin{array}{l}5-\mathrm{FU} \\
\text { prodrugs }\end{array}$ & $\begin{array}{c}\text { TDM } \\
\text { analysis }\end{array}$ & $\begin{array}{l}\text { Sampling time } \\
\text { (hour) }\end{array}$ & $\begin{array}{l}\text { Sampling day } \\
\text { (Day) }\end{array}$ & $\begin{array}{c}\text { Dosage } \\
\text { adjustment }\end{array}$ & Cotreatment & $\begin{array}{c}\text { OS } \\
\text { (Months) }\end{array}$ \\
\hline $\begin{array}{l}\text { Tominaga } \\
(48)\end{array}$ & 2004 & 1 & GC & HD & TS-1 & NA & $\begin{array}{c}1^{\text {st } H D: 0,2,4,6,8,24} \\
2^{\text {nd }} H D: 1,2,4,72\end{array}$ & 1,3 & $100 \mathrm{mg} /$ Day & - & NA \\
\hline $\begin{array}{l}\text { Yamamoto } \\
(49)\end{array}$ & 2005 & 1 & GC & $\begin{array}{l}\text { Impaired } \\
\text { renal } \\
\text { function }\end{array}$ & TS-1 & NA & $0,2,4,6,10,24$ & 1,5 & 120 mg/Day & - & About 2 \\
\hline $\begin{array}{l}\text { Tanaka } \\
(50)\end{array}$ & 2005 & 1 & GC & HD & TS-1 & GC-MS & $0,3,5,24,43,48$ & 1 & $\begin{array}{l}80-100 \\
\mathrm{mg} / \text { Day }\end{array}$ & - & 7,5 \\
\hline $\begin{array}{l}\text { Yoshida } \\
\text { (51) }\end{array}$ & 2015 & 1 & CRC & $\begin{array}{c}\text { DPD- } \\
\text { deficient }\end{array}$ & Capecitabine & HPLC & 0,2 & $1,2,4,6,8$ & $\begin{array}{c}300-1800 \\
\mathrm{mg} / \text { Day }\end{array}$ & $\begin{array}{c}\text { Oxaliplatin } \\
\text { Bevacizumab }\end{array}$ & NA \\
\hline $\begin{array}{l}\mathrm{Li} \\
(52)\end{array}$ & 2019 & 1 & $\mathrm{CRC}$ & $\begin{array}{l}\text { X-linked } \\
\text { agammaglo- } \\
\text { bulinemia }\end{array}$ & Capecitabine & NA & NA & NA & $1000 \mathrm{mg} / \mathrm{m}^{2}$ & $\begin{array}{l}\text { Oxaliplatin } \\
\text { Cetuximab }\end{array}$ & 7,5 \\
\hline
\end{tabular}

GC: Gastric cancer; CRC: colorectal cancer; HD: hemodialysis; DPD: dihydropyrimidine dehydrogenase; TDM: therapeutic drug monitoring; GCMS: gas chromatography-mass spectrometry; HPLC: high performance liquid chromatography; OS: overall survival.

levels in plasma did not necessarily reflect the levels in healthy tissues and tumours after capecitabine treatment (45). Capecitabine is thought to be selectively converted to 5-FU in tumours via a cascade of three enzymes. According to measurements of 5-FU blood levels after capecitabine administration, capecitabine is not considered to be converted to 5-FU in the blood. Therefore, inhibitors of the three enzymes have not been examined, and there have been no reports of attempts to measure the blood concentration of 5-FU in the presence of an enzyme inhibitor after administration of capecitabine. However, Yoshida reported for the first time the 5-FU concentration in the blood after a TP inhibitor (5-nitrouracil) was added to a blood sample. The results showed that the 5-FU plasma concentration differed depending on the time from blood collection to measurement, the temperature at the time of measurement, and the presence or absence of the TP inhibitor 5-nitrouracil (46). In view of Yoshida's report, it is preferable to measure the blood 5-FU concentration immediately after blood collection, but this is not practical in actual clinical settings for various reasons. Esther reported that the optimal sampling times for TDM of capecitabine to maximize the information obtained consisted of blood sampling at $0.5,1$, $1.5,5$, and 8 hours after drug administration (47). A risk of incorrect TDM and incorrect dosage adjustment exists because of differences in time, temperature, and the presence of metabolic enzymes. Therefore, it is very important to accurately measure the blood concentration, but further research on this subject is needed.

At present, TDM is being performed to elucidate the pharmacokinetic properties of drugs. However, there are some case reports of dose adjustment of 5-FU prodrugs by TDM (Table II) (48-52). Tanaka reported that TDM of S-1 was used in patients with recurrent gastric cancer undergoing maintenance dialysis to estimate the appropriate S-1 dose and administer treatment. Fifty percent (50 mg/day) or $40 \%$ (40 mg/day) of the reference dose of S-1 was orally administered immediately after dialysis every other day, and TDM was performed for a total of 16 blood collection points using gas chromatography. As a result, the AUC at the time of administration of $40 \mathrm{mg} /$ day was equivalent to that at the time of administration of $100 \mathrm{mg} /$ day, which is a safe dose for patients with normal renal function. Treatment was performed with S-1 for a total of 4 months, and 11 cycles of administration every other day were considered one cycle. The only adverse event was mild stomatitis, and control of ascites was possible (50).

Tominaga performed TDM at 31 blood sampling points in patients with gastric cancer liver metastases undergoing maintenance dialysis. As a result, $50 \mathrm{mg} / \mathrm{dose}$, corresponding to $41.7 \%$ of the reference dose of S-1 (128 mg/day), was administered immediately after dialysis three times a week, and a response was obtained without adverse events (48). Yoshida performed TDM of capecitabine in a colon cancer patient with DPD deficiency, and the dose was adjusted while observing side effects (51). Li reported that TDM of capecitabine was performed in immunodeficient X-linked agammaglobulinaemia colorectal cancer patients, and the dose was adjusted while focusing on the appearance of toxicity (52).

TDM of 5-FU has begun to be introduced clinically for personalized therapy, while TDM of 5-FU prodrugs has only been performed to elucidate the pharmacokinetic properties.

There are no reports of prospective clinical studies on dose control. Currently, we are entering an era where cancer gene analysis can be used to select appropriate anticancer drugs. However, it is not possible to determine the amount 
of anticancer drug by genetic analysis. If serious side effects occur because of the administration of a selected anticancer drug, the treatment must be discontinued. 5-FU is characterized by a narrow therapeutic window and strong exposure-toxicity relationship, which support the use of approaches to monitor drug administration. Individualized treatment with TDM is expected to optimize therapy and will be indispensable for effective cancer gene analysis and treatment in the future.

\section{Conclusion}

At present, personalized treatment with TDM of 5-FU prodrugs has not been applied in daily clinical practice. In the future, it will be necessary to consider individualized treatment with TDM in large-scale prospective studies.

\section{Conflicts of Interest}

The Authors declare no conflicts of interest in regard to this study.

\section{Authors' Contributions}

Y.H. and Y.Y. contributed to study concept and design, analysis, and interpretation of data, drafting of the manuscripts. T.Y., N.A., G.Y., and F.Y. contributed to the acquisition of data and research performance. S.H. revised the manuscript. All Authors approved the final version of the manuscript.

\section{Acknowledgements}

The Authors would like to thank Lisa Kreiner, $\mathrm{PhD}$, from Edanz Group (https://en-author-services.edanzgroup.com/) for editing a draft of this manuscript.

\section{References}

1 Beumer JH: Without therapeutic drug monitoring, there is no personalized cancer care. Clin Pharmacol Ther 93(3): 228-230, 2013. PMID: 23419487. DOI: 10.1038/clpt.2012.243

2 Beumer JH, Chu E and Salamone SJ: Body-surface area-based chemotherapy dosing: appropriate in the $21^{\text {st }}$ century? J Clin Oncol 30(31): 3896-3897, 2012. PMID: 22965963. DOI: 10.1200/JCO.2012.44.2863

3 Maeda K, Shibutani M, Otani H, Fukuoka T, Iseki Y, Matsutani $\mathrm{S}$, Nagahara H, Inoue T, Tachimori A, Nishii T, Miki Y, Hosono $\mathrm{M}$ and Ohira M: Neoadjuvant radiotherapy with capecitabine plus bevacizumab for locally advanced lower rectal cancer: results of a single-institute phase II study. Anticancer Res 38(7): 4193-4197, 2018. PMID: 29970549. DOI: 10.21873/anticanres.12713

4 Suenaga M, Akiyoshi T, Shinozaki E, Fujimoto Y, Matsusaka S, Konishi T, Nagayama S, Fukunaga Y, Kawakami K, Yokokawa T, Sugisaki T, Ueno M and Yamaguchi T: A feasibility study of capecitabine and oxaliplatin for patients with stage II/III colon cancer -ACTOR study. Anticancer Res 38(3): 1741-1747, 2018. PMID: 29491111. DOI: 10.21873/anticanres.12410
5 Felici A, Verweij J and Sparreboom A: Dosing strategies for anticancer drugs: the good, the bad and body-surface area. Eur J Cancer 38(13): 1677-1684, 2002. PMID: 12175683. DOI: 10.1016/s0959-8049(02)00151-x

6 Saif MW, Choma A, Salamone SJ and Chu E: Pharmacokinetically guided dose adjustment of 5-fluorouracil: a rational approach to improving therapeutic outcomes. J Natl Cancer Inst 101(22): 1543-1552, 2009. PMID: 19841331. DOI: $10.1093 /$ jnci/djp328

7 Gamelin E and Boisdron-Celle M: Dose monitoring of 5fluorouracil in patients with colorectal or head and neck cancer-status of the art. Crit Rev Oncol Hematol 30(1): 71-79, 1999. PMID: 10439055. DOI: 10.1016/s1040-8428(98)00036-5

8 Milano G, Etienne MC, Renee N, Thyss A, Schneider M, Ramaioli A and Demard F: Relationship between fluorouracil systemic exposure and tumor response and patient survival. J Clin Oncol 12(6): 1291-1295, 1994. PMID: 8201391. DOI: 10.1200/JCO.1994.12.6.1291

9 Gamelin E, Delva R, Jacob J, Merrouche Y, Raoul JL, Pezet D, Dorval E, Piot G, Morel A and Boisdron-Celle M: Individual fluorouracil dose adjustment based on pharmacokinetic followup compared with conventional dosage: results of a multicenter randomized trial of patients with metastatic colorectal cancer. J Clin Oncol 26(13): 2099-2105, 2008. PMID: 18445839. DOI: 10.1200/JCO.2007.13.3934

10 Farkouh A, Ettlinger D, Schueller J, Georgopoulos A, Scheithauer W and Czejka M: A rapid and simple HPLC assay for quantification of capecitabine for drug monitoring purposes. Anticancer Res 30(12): 5207-5211, 2010. PMID: 21187514.

11 Buchner P, Mihola E, Sahmanovic A, Steininger T, Dittrich C and Czejka M: Validation of a simple assay for the quantification of the capecitabine metabolites 5'-DFCR and 5'DFUR for drug monitoring in patients receiving outpatient chemotherapy. Anticancer Res 33(3): 881-886, 2013. PMID: 23482757.

12 Thorat SG, Chikhale RV and Tajne MR: Development and validation of HPLC and HPTLC methods for therapeutic drug monitoring of capecitabine in colorectal cancer patients. J Chromatogr Sci 57(10): 892-900, 2020. PMID: 31609432. DOI: 10.1093/chromsci/bmz067

13 Goodman DW: Lisdexamfetamine dimesylate: the first prodrug stimulant. Psychiatry (Edgmont) 4(8): 39-45, 2007. PMID: 20532026.

14 Wagstaff AJ, Ibbotson T and Goa KL: Capecitabine: a review of its pharmacology and therapeutic efficacy in the management of advanced breast cancer. Drugs 63(2): 217-236, 2003. PMID: 12515569. DOI: 10.2165/00003495-200363020-00009

15 Cavallaro G, Licciardi M, Caliceti P, Salmaso S and Giammona G: Synthesis, physico-chemical and biological characterization of a paclitaxel macromolecular prodrug. Eur J Pharm Biopharm 58(1): 151-159, 2004. PMID: 15207549. DOI: 10.1016/j.ejpb.2004.02.012

16 Hiller $S$, Zhuk $R$, Lidak $M$ and Zidermane A: Patent specification 1168391. Br Patent 1: 391-395, 1968.

17 Fujii S, Ikenaka K, Fukushima M and Shirasaka T: Effect of uracil and its derivatives on antitumor activity of 5-fluorouracil and 1-(2-tetrahydrofuryl)-5-fluorouracil. Gan 69(6): 763-772, 1978. PMID: 750271.

18 Ikenaka K, Shirasaka T, Kitano S and Fujii S: Effect of uracil on metabolism of 5-fluorouracil in vitro. Gan 70(3): 353-359, 1979. PMID: 467897. 
19 Yamamoto J, Toide K, Haruno A, Yoshimura Y and Unemi N: General pharmacological properties of UFT, a new type of anticancer agent consisting of 1-(2-tetrahydrofuryl)-5-fluorouracil (FT) and uracil. I: Pharmacological analysis of the combined effect of FT and uracil. Arzneimittelforschung 31(8): 1268-1278, 1981. PMID: 6794578.

20 Tatsumi K, Fukushima M, Shirasaka T and Fujii S: Inhibitory effects of pyrimidine, barbituric acid and pyridine derivatives on 5-fluorouracil degradation in rat liver extracts. Jpn J Cancer Res 78(7): 748-755, 1987. PMID: 3114201.

21 Shirasaka T, Shimamoto Y and Fukushima M: Inhibition by oxonic acid of gastrointestinal toxicity of 5-fluorouracil without loss of its antitumor activity in rats. Cancer Res 53(17): 40044009, 1993. PMID: 7689420.

22 Hoshi A, Iigo M, Yoshida M and Kuretani K: Antitumor activity of carbamoyl derivatives of 5-fluorouracil by oral administration. Gan 66(6): 673-674, 1975. PMID: 1225720.

23 Realini N, Solorzano C, Pagliuca C, Pizzirani D, Armirotti A, Luciani R, Costi MP, Bandiera T and Piomelli D: Discovery of highly potent acid ceramidase inhibitors with in vitro tumor chemosensitizing activity. Sci Rep 3: 1035, 2013. PMID: 23301156. DOI: 10.1038/srep01035

24 Sumizawa T, Furukawa T, Haraguchi M, Yoshimura A, Takeyasu A, Ishizawa M, Yamada $\mathrm{Y}$ and Akiyama S: Thymidine phosphorylase activity associated with platelet-derived endothelial cell growth factor. J Biochem 114(1): 9-14, 1993. PMID: 8407883. DOI: 10.1093/oxfordjournals.jbchem.a124146

25 Moghaddam A, Zhang HT, Fan TP, Hu DE, Lees VC, Turley H, Fox SB, Gatter KC, Harris AL and Bicknell R: Thymidine phosphorylase is angiogenic and promotes tumor growth. Proc Natl Acad Sci USA 92(4): 998-1002, 1995. PMID: 7532308. DOI: $10.1073 /$ pnas.92.4.998

26 Fox SB, Westwood M, Moghaddam A, Comley M, Turley H, Whitehouse RM, Bicknell R, Gatter KC and Harris AL: The angiogenic factor platelet-derived endothelial cell growth factor/thymidine phosphorylase is up-regulated in breast cancer epithelium and endothelium. Br J Cancer 73(3): 275-280, 1996. PMID: 8562330. DOI: 10.1038/bjc.1996.49

27 Toi M, Hoshina S, Taniguchi T, Yamamoto Y, Ishitsuka H and Tominaga T: Expression of platelet-derived endothelial cell growth factor/thymidine phosphorylase in human breast cancer. Int J Cancer 64(2): 79-82, 1995. PMID: 7542228. DOI: 10.1002/ijc.2910640202

28 Walko CM and Lindley C: Capecitabine: a review. Clin Ther 27(1): 23-44, 2005. PMID: 15763604. DOI: $10.1016 /$ j.clinthera.2005.01.005

29 Salamone S, Li Y, Courtney J, Harney R, Lundell G and Stocker D: 5-Fluorouracil determination in plasma by rapid nanoparticle immunoassay; Highlights from: 5-Fluorouracil Drug Management Pharmacokinetics and Pharmacogenomics Workshop; Orlando, Florida; January 2007. Clin Colorectal Cancer 6(6): 419-420, 2007.

30 Büchel B, Sistonen J, Joerger M, Aebi Y, Schürch S and Largiadèr CR: Comparative evaluation of the My5-FU ${ }^{\mathrm{TM}}$ immunoassay and LC-MS/MS in monitoring the 5-fluorouracil plasma levels in cancer patients. Clin Chem Lab Med 51(8): 1681-1688, 2013. PMID: 23412878. DOI: 10.1515/cclm-2012-0641

31 Santini J, Milano G, Thyss A, Renee N, Viens P, Ayela P, Schneider $\mathrm{M}$ and Demard F: 5-FU therapeutic monitoring with dose adjustment leads to an improved therapeutic index in head and neck cancer. Br J Cancer 59(2): 287-290, 1989. PMID: 2930694. DOI: 10.1038/bjc. 1989.59

32 Gamelin E, Boisdron-Celle M, Delva R, Regimbeau C, Cailleux PE, Alleaume C, Maillet ML, Goudier MJ, Sire M, Person-Joly MC, Maigre M, Maillart P, Fety R, Burtin P, Lortholary A, Dumesnil Y, Picon L, Geslin J, Gesta P, Danquechin-Dorval E, Larra F and Robert J: Long-term weekly treatment of colorectal metastatic cancer with fluorouracil and leucovorin: results of a multicentric prospective trial of fluorouracil dosage optimization by pharmacokinetic monitoring in 152 patients. J Clin Oncol 16(4): 1470-1478, 1998. PMID: 9552054. DOI: 10.1200/JCO.1998.16.4.1470

33 Fety R, Rolland F, Barberi-Heyob M, Hardouin A, Campion L, Conroy T, Merlin JL, Riviere A, Perrocheau G, Etienne MC and Milano G: Clinical impact of pharmacokinetically-guided dose adaptation of 5-fluorouracil: results from a multicentric randomized trial in patients with locally advanced head and neck carcinomas. Clin Cancer Res 4(9): 2039-2045, 1998. PMID: 9748117

34 Ychou M, Duffour J, Kramar A, Debrigode C, Gourgou S, Bressolle F and Pinguet F: Individual 5-FU dose adaptation in metastatic colorectal cancer: results of a phase II study using a bimonthly pharmacokinetically intensified LV5FU2 regimen. Cancer Chemother Pharmacol 52(4): 282-290, 2003. PMID: 12827293. DOI: $10.1007 / \mathrm{s} 00280-003-0658-0$

35 Saam J, Critchfield GC, Hamilton SA, Roa BB, Wenstrup RJ and Kaldate RR: Body surface area-based dosing of 5-fluoruracil results in extensive interindividual variability in 5-fluorouracil exposure in colorectal cancer patients on FOLFOX regimens. Clin Colorectal Cancer 10(3): 203-206, 2011. PMID: 21855044. DOI: $10.1016 /$ j.clcc.2011.03.015

36 Capitain O, Asevoaia A, Boisdron-Celle M, Poirier AL, Morel $A$ and Gamelin E: Individual fluorouracil dose adjustment in FOLFOX based on pharmacokinetic follow-up compared with conventional body-area-surface dosing: a phase II, proof-ofconcept study. Clin Colorectal Cancer 11(4): 263-267, 2012. PMID: 22683364. DOI: 10.1016/j.clcc.2012.05.004

37 Kline CL, Schiccitano A, Zhu J, Beachler C, Sheikh H, Harvey HA, Mackley HB, McKenna K, Staveley-O’Carroll K, Poritz L, Messaris E, Stewart D, Sivik J and El-Deiry WS: Personalized dosing via pharmacokinetic monitoring of 5-fluorouracil might reduce toxicity in early- or late-stage colorectal cancer patients treated with infusional 5-fluorouracil-based chemotherapy regimens. Clin Colorectal Cancer 13(2): 119-126, 2014. PMID: 24461492. DOI: 10.1016/j.clcc.2013.11.001

38 Patel JN, O’Neil BH, Deal AM, Ibrahim JG, Sherrill GB, Olajide OA, Atluri PM, Inzerillo JJ, Chay CH, McLeod HL and Walko CM: A community-based multicenter trial of pharmacokinetically guided 5-fluorouracil dosing for personalized colorectal cancer therapy. Oncologist 19(9): 959965, 2014. PMID: 25117066. DOI: 10.1634/theoncologist.20140132

39 Wilhelm M, Mueller L, Miller MC, Link K, Holdenrieder S, Bertsch T, Kunzmann V, Stoetzer OJ, Suttmann I, Braess J, Birkmann J, Roessler M, Moritz B, Kraff S, Salamone SJ and Jaehde U: Prospective, multicenter study of 5-fluorouracil therapeutic drug monitoring in metastatic colorectal cancer treated in routine clinical practice. Clin Colorectal Cancer 15(4): 381-388, 2016. PMID: 27256667. DOI: 10.1016/j.clcc.2016.04.001

40 Denda T, Kanda M, Morita Y, Kim HM, Kashiwada T, Matsuda C, Fujieda S, Nakata K, Murotani K, Oba K, Sakamoto J and 
Mishima H: Pharmacokinetic dose adjustment of 5-FU in modified FOLFOX7 plus bevacizumab for metastatic colorectal cancer in Japanese patients: a-JUST phase II clinical trial. Cancer Chemother Pharmacol 78(6): 1253-1261, 2016. PMID: 27807652. DOI: $10.1007 / \mathrm{s} 00280-016-3184-6$

41 Deng R, Shi L, Zhu W, Wang M, Guan X, Yang D and Shen B: Pharmacokinetics-based dose management of 5-fluorouracil clinical research in advanced colorectal cancer treatment. Mini Rev Med Chem 20(2): 161-167, 2020. PMID: 31660826. DOI: $10.2174 / 1389557519666191011154923$

42 Kaldate RR, Haregewoin A, Grier CE, Hamilton SA and McLeod HL: Modeling the 5-fluorouracil area under the curve versus dose relationship to develop a pharmacokinetic dosing algorithm for colorectal cancer patients receiving FOLFOX6. Oncologist 17(3): 296-302, 2012. PMID: 22382460. DOI: 10.1634/theoncologist.2011-0357

43 Kochi M, Fujii M, Kanamori N, Kaiga T, Aizaki K, Takahashi $\mathrm{T}$ and Takayama $\mathrm{T}$ : Effect of gastrectomy on the pharmacokinetics of S-1, an oral fluoropyrimidine, in resectable gastric cancer patients. Cancer Chemother Pharmacol 60(5): 693-701, 2007. PMID: 17690883. DOI: 10.1007/s00280-0070415-x

44 Yasui H, Kawakami T, Kashiwagi H, Mori K, Omae K, Kasai J, Yoshisue K, Kawahira M, Tsushima T, Machida N, Fukutomi A and Yamaguchi K: Pharmacokinetics of S-1 monotherapy in plasma and in tears for gastric cancer patients. Int J Clin Oncol 24(6): 660-665, 2019. PMID: 31011915. DOI: 10.1007/s10147018-01387-6

45 Gieschke R, Burger HU, Reigner B, Blesch KS and Steimer JL: Population pharmacokinetics and concentration-effect relationships of capecitabine metabolites in colorectal cancer patients. Br J Clin Pharmacol 55(3): 252-263, 2003. PMID: 12630975. DOI: 10.1046/j.1365-2125.2003.01765.x

46 Yoshida Y, Hashimoto Y, Miyazaki M, Aisu N, Yamada T, Kajitani R, Munechika T, Matsumoto Y, Nagano H, Shimaoka H, Komono A, Sakamoto R, Yoshimatsu G, Yoshimura F, Kiyomi F and Hasegawa S: 5-Nitrouracil stabilizes the plasma concentration values of 5-FU in colorectal cancer patients receiving capecitabine. Sci Rep 10(1): 2711, 2020. PMID: 32066801. DOI: 10.1038/s41598-020-59648-2
47 Oyaga-Iriarte E, Insausti A, Bueno L, Sayar O and Aldaz A: Mining small routine clinical data: a population pharmacokinetic model and optimal sampling times of capecitabine and its metabolites. J Pharm Pharm Sci 22(1): 112-121, 2019. PMID: 30964613. DOI: 10.18433/jpps30392

48 Tominaga K, Higuchi K, Okazaki H, Suto R, Hamaguchi M, Tanigawa T, Sasaki E, Shiba M, Watanabe T, Fujiwara Y, Oshitani N, Matsumoto T and Arakawa T: Safety and efficacy of S-1, a novel oral fluorouracil antitumor drug, for a chronic renal failure patient maintained on hemodialysis. Oncology 66(5): 358-364, 2004. PMID: 15331922 . DOI: $10.1159 / 000079483$

49 Yamamoto K, Imamura H, Furukawa H, Kishimoto T, Tanaka J, Oshiro R, Tatsuta M, Masutani S, Fukunaga M, Nakayama T, Takemoto H, Kondo M, Kamigaki S and Kawasaki T: [A trial of TS-1 administration on the basis of the pharmacokinetic study for an advanced gastric cancer patient with impaired renal function]. Gan To Kagaku Ryoho 32(11): 1748-1751, 2005. PMID: 16315929.

50 Tanaka T, Fujita S, Tanaka N, Ooka M, Okajima S and Tanaka $\mathrm{N}$ : [TS-1 treatment for progressive gastric cancer in a patient on chronic dialysis - assessment of dosage regimen by monitoring blood concentrations of therapeutic drugs (TDM)]. Gan To Kagaku Ryoho 32(6): 841-845, 2005. PMID: 15984528.

51 Yoshida Y, Ogura K, Hiratsuka A, Aisu N, Yamada T, Kojima D, Tanimura S, Ogata K, Hara S, Mogi A, Takamatsu Y, Tamura K, Mishima H and Yamashita Y: 5-Fluorouracil chemotherapy for dihydropyrimidine dehydrogenase-deficient patients: Potential of the dose-escalation method. Anticancer Res 35(9): 4881-4887, 2015. PMID: 26254383.

52 Li M, Chen W, Sun X, Wang Z, Zou X, Wei H, Wang Z and Chen W: Metastatic colorectal cancer and severe hypocalcemia following irinotecan administration in a patient with X-linked agammaglobulinemia: a case report. BMC Med Genet 20(1): 157, 2019. PMID: 31510946. DOI: 10.1186/s12881-019-0880-1

Received May 23, 2020

Revised June 21, 2020

Accepted June 22, 2020 